\title{
Marianne Hulsbosch
}

Pointy Shoes and Pith Helmets. Dress and Identity Construction in Ambon from 1850 to 1942. Leiden/Boston: Brill, 2015, $\mathrm{x}+237$ pp. ISBN 9789067183390. Price: EUR 116.00 (hardback).

It has been two decades since Emma Tarlo, in her original book Clothing Matters, posited that the study of dress and sartorial regimes in colonial societies should focus on the 'problem of what to wear rather than the description of what is worn' (Tarlo 1996: p. 8). In Pointy Shoes and Pith Helmets, an investigation of dress and identity formation during the last century of colonial rule in Ambon, Marianne Hulsbosch demonstrates she has taken Tarlo's words to heart. In this richly illustrated publication she explores the development of dress systems in Ambon from roughly $185^{\circ}$ till 1942 and examines why and how these systems were employed and to what effect.

Hulsbosch asserts that dress is more than an item of clothing, as it incorporates the act of dressing and adorning the body, which creates both individual and group identities that reflect political disposition, ethnicity (race), class, and gender. One of the major challenges for the Ambonese, Hulsbosch posits, was to remain true to their ethnic identity under the constraints of colonialism. Complicating matters was that many Christian Ambonese served in the colonial army or were otherwise associated with the Dutch colonial regime. Consequently, one would expect that the growing Westernization of colonial society from the late nineteenth century onwards would be reflected in the primacy of Western style dress among the Ambonese. Instead, as Hulsbosch convincingly argues, it was the threatened loss of identity that strengthened resolve among the ethnic Ambonese to develop dress systems that continued to represent their core cultural principles and values. Significantly, women were absolutely crucial to this development as they 'rescued Ambonese identity from irreverence' by successfully merging cultural Adat principles, Christian puritan values, and modern technologies (p. 187).

As with dress, the appearance of Pointy Shoes and Pith Helmets can be deceiving. At first glance the publication appears to be a coffee table book, but upon reading the prologue one is struck by the theoretical depths Hulsbosch has immersed her study in. She has adopted Arthur Frank's Typology of Body Use in Action model to examine dress practices through which identity is defined (Frank 1996). While Frank designed his model to study different body types and their active and reactive interactions within society, Hulsbosch, arguing that dress is an extension of the body, applied Frank's model to the study of dress systems in colonial Ambon. Hulsbosch proposes four dress typologies: disciplined dress, dominating dress, mirroring dress, and communicative dress.

(C) ARNOUT H.C. VAN DER MEER, 2017 | DOI: 10.1163/22134379-17301011 
Each of these typologies corresponds to a particular combination of four dress experiences, namely control (predictable or contingent), desire (lacking or producing), other-relatedness (dyadic or monadic), and self-relatedness (disassociated or associated). Although Hulsbosch acknowledges these dress typologies are in reality never clear-cut, it provides her study with a framework to dissect the development of different systems of dress.

In addition to the prologue, Pointy Shoes and Pith Helmets consists of five chapters and a concluding epilogue. The first chapter is an overview of Ambonese society under colonial rule that subtly introduces the various Portuguese, Dutch, Christian, and Islamic influences on Ambonese dress throughout the colonial period. In the remaining four chapters Hulsbosch explores the four dress typologies she introduced in the prologue. For instance, the second chapter focuses on disciplined dress, which she describes as a dress style that was dissociated from the self and instead was concerned with membership and position within the Ambonese community. Hulsbosch's discussion of how the sartorial hierarchy was reflected in women's wear, one of the most interesting sections of the book, illustrates this wonderfully. In fact, one's social position was named after a dress item: Nona Kebaya (working class women donning the traditional black kebaya (upper-body garment for women)), Nona Duduk Rumah (stay at home girl who wore a white kebaya in public), Nona Cenela (Christian Ambonese middle-class women recognizable by their slippers (cenela) and batik sarong), Nyonya Kaus (elderly middle-class women with more elaborate slipper and sarong), Nona Rok (upper-middle class women and Eurasians who wore skirts), Nona Militair (spouses of soldiers identifiable by their Javanese dress), and Nona Jurk (Eurasian women in Western dresses married to European men). Similarly, the subsequent chapters deal with dominating dress (religious dress, military uniforms, and the tropical/colonial suit), mirroring dress (adoption of ethnic Ambonese dress by Europeans within the privacy of their home and of Western dress by the Ambonese in public), and communicative dress (celebration of ethnic identity during life rites, cultural activities, and weddings).

Just as the spice islands of the Moluccas had an impact on history far beyond their size, Pointy Shoes and Pith Helmets should not only appeal to specialists of Ambonese or Indonesian history, but to all scholars fascinated with dress systems or sartorial hierarchies in colonial or multicultural contexts. It is precisely the confined geographical and social scope that makes Hulsbosch's study so valuable, as it allows her to explore the importance of dress systems in far greater detail than many other more generic studies have done. In addition, her work is based upon a unique assembly of sources, such as oral interviews with contemporaries, study of archival and private photograph collections, material 
objects (as dress items), personal accounts (as diaries and correspondence), and oral traditions.

To her credit, Hulsbosch employs a comparative framework that elucidates her study and invites comparison with other colonial contexts. Yet at the same time, the theoretical emphasis throughout the book makes it at times appear devoid of human actors and agency. One wonders if Hulsbosch could not have used more of her unique source materials to enliven her narrative with anecdotes or vignettes. Similarly, while this is a stunningly beautiful publication, save some minor issues such as image repetition or quality, the book would have benefited from integrating the imagery more closely into the text. Often, there is no reference to or discussion of images that seem far more important than mere decoration to this study.

In the end, Pointy Shoes and Pith Helmets is a valuable contribution to the study of Ambonese, Indonesian, and colonial history that fascinates from beginning to end. It is a must read for scholars interested in cultural history in general.

Arnout H.C. van der Meer

Colby College

Arnout.van.der.meer@colby.edu

\section{References}

Frank, Arthur, (1991) 'For a Sociology of the Body. An Analytical Review', in: H.A.T. Featherstone (ed.), The Body. Social Process and Cultural Theory (Vol. 5). London: Sage Publications.

Tarlo, Emma (1996) Clothing Matters. Dress and Identity in India. Chicago: The University of Chicago Press. 